\author{
Małgorzata Kolankowska (iD https://orcid.org/0000-0002-9804-9210 \\ Uniwersytet Wrocławski \\ malgorzata.kolankowska@uwr.edu.pl
}

\title{
Tropem Kapuścińskiego w Hiszpanii - o poszukiwaniu odniesień oraz dziennikarskich inspiracji
}

\section{On the Trail of Kapuściński in Spain - on the Search of References and Journalistic Inspirations}

\begin{abstract}
The aim of the article is the search for the sources of fascination with Kapuściński's oeuvre in the Spanish academic milieu. In the essay discussed were the examples of actions taken by the researchers in Spain and in Poland whose idea was to propagate the thoughts of the author of The Shadow of Sun. The article shows that Kapuściński's reflections on the topic of the journalist and corespondent profession are still relevant and many Spanish journalists invoke them in their work in a direct or indirect manner.
\end{abstract}

Keywords: Kapuściński, reportage, reception, war correspondent

Streszczenie: Celem artykułu jest poszukiwanie źródeł fascynacji twórczością Ryszarda Kapuścińskiego w hiszpańskim środowisku akademickim. W eseju omówiono przykłady działań podejmowanych przez badaczy w Hiszpanii i w Polsce, których ideą było propagowanie myśli autora Hebanu. Artykuł wskazuje, że refleksje Kapuścińskiego na temat zawodu reportera i korespondenta są wciąż aktualne, a wielu hiszpańskich dziennikarzy odwołuje się do nich w swojej pracy w sposób bezpośredni lub pośredni.

Słowa kluczowe: Kapuściński, reportaż, recepcja, korespondent wojenny

\section{Uwagi wstępne}

Kilkanaście lat temu poznałam dziennikarza i wykładowcę akademickiego, prof. José Luisa Gonzáleza Estebana ${ }^{1}$, który przyjechał do Wrocławia, aby uczestniczyć w konferencji poświęconej mediom i terroryzmowi w związku z zamachem

${ }^{1}$ Wówczas pracował na Universidad CEU Cardenal Herrera, obecnie pełni funkcję prorektora ds. międzynarodowych na Uniwersytecie im. Miguela Hernandeza w Elche (Hiszpania). 
11 marca 2004 roku w Madrycie. Przy okazji wspominał o swojej fascynacji Ryszardem Kapuścińskim. Później długo zabiegał o spotkanie z polskim dziennikarzem, a przede wszystkim o nadanie mu tytułu honoris causa swojej uczelni (wówczas CEU - Universidad Cardenal Herrera). Już wtedy zastanowiło mnie, co sprawiło, że autor Hebanu, zwany Kapu, stał się tak bliski Hiszpanom, że przyznali mu jedną z najbardziej prestiżowych nagród - Nagrodę Księcia Asturii w 2003 roku. W niniejszym eseju postanowiłam zatem przyjrzeć się źródłom owej fascynacji i opisać przykłady wybranych działań, praktyk i odwołań wskazujących na fakt, że myśl o polskim dziennikarzu wciąż pozostaje żywa, pomimo publikacji biografii Kapuściński non-fiction, która na polskim gruncie wywołała liczne dyskusje i nadwerężyła nieco wizerunek Ryszarda Kapuścińskiego. W tekście skupiłam się głównie na pozytywnym wizerunku polskiego pisarza w środowisku akademickim i dziennikarskim.

\section{Seminaria poświęcone twórczości Ryszarda Kapuścińskiego}

Wracając do Gonzáleza Estebana, należy podkreślić, że uczelnia odrzuciła kandydaturę Kapuścińskiego, a do spotkania z polskim reporterem nie doszło z powodu pogarszającego się stanu zdrowia pisarza. Wówczas zrodził się nowy pomysł - González Esteban, zmieniwszy miejsce pracy na Uniwersytet im. Miguela Hernándeza w Elche, postanowił zorganizować polsko-hiszpańskie seminarium poświęcone twórczości Ryszarda Kapuścińskiego. Zaczął się coraz bardziej intensywnie przyglądać pracy polskiego reportera, zwłaszcza w wymiarze etyczno-dziennikarskim. To, co zwróciło jego uwagę, to kontestowanie rzeczywistości, sposób traktowania źródeł, a przede wszystkim, jak to określa González Esteban, „dziennikarstwo na wolnym ogniu”", które i on sam starał się zawsze realizować. Hiszpański medioznawca podkreśla, że Kapuściński był pionierem w zakresie stosowania nowych metod narracji, w skupianiu się na detalach, wychodzeniu poza tę, niekiedy nudną i żmudną, pracę:

Kapuściński jest często cytowany przez hiszpańskich dziennikarzy. Stanowi swoisty punkt odniesienia. Na przykład dla Ramóna Lobo, Olgi Rodríguez, Xaviera Aldekoi. Cytuje się go głównie ze względu na sposób postrzegania dziennikarstwa. To dziennikarstwo wysokiej jakości, którego bardzo nam potrzeba i które, na szczęście, się odradza. Pojawia się również coraz więcej mediów, które opowiadają się za takim właśnie postrzeganiem dziennikarstwa³

${ }^{2}$ Na podstawie wywiadu przeprowadzonego przez autorkę z prof. José Luisem Gonzálezem Estebanem na potrzeby niniejszego artykułu, 11.06.2021 (online). Wszystkie tłumaczenia z języka hiszpańskiego są własne - M.K.

${ }^{3}$ Tamże. 
Założeniem projektu seminariów było stworzenie swego rodzaju hiszpańsko-polskich sieci lączących ludzi ze środowisk akademickiego i dziennikarskiego, dla których myśl Kapuścińskiego była wciąż żywa i ważna. W pierwotnym planie zakładano, że spotkania będą się odbywały cyklicznie w Hiszpanii i w Polsce jako bliźniacze seminaria, w których uczestniczyć będą goście z obu krajów. Ich wspólną ideą był dialog, wymiana myśli, próba skonfrontowania różnych perspektyw. Łącznie odbyło się ich siedem w Elche i cztery we Wrocławiu. Były to kolejno:

- I Seminario Internacional Ryszard Kapuściński “Análisis del Ímperio" - maj 2009 roku,

- bliźniacze seminarium w Instytucie Dziennikarstwa i Komunikacji Społecznej Uniwersytetu Wrocławskiego pt. „Spotkania z Kapuścińskim: Cesarz Ryszarda Kapuścińskiego. Recepcja dzieła w Polsce i w Hiszpanii” - kwiecień 2010 roku,

- II Seminario Internacional Ryszard Kapuściński "Análisis de El Emperador" maj 2010 roku,

- bliźniacze seminarium w Instytucie Dziennikarstwa i Komunikacji Społecznej Uniwersytetu Wrocławskiego pt. „II Spotkania z Kapuścińskim” - kwiecień 2011 roku,

- III Seminario Internacional Ryszard Kapuściński - przełom kwietnia i maja 2011 roku,

- IV Seminario Internacional Ryszard Kapuściński de Periodismo, Derechos Humanos, Migración y Fronteras XIII Jornadas de Periodismo UMH - listopad 2017 roku,

- (V Seminarium - nie miało w tytule odwołania do Ryszarda Kapuścińskiego, ale z założenia było kontynuacją rozważań z IV Seminario - tym razem na polskim gruncie) Wrocławska konferencja pt. „(Re)prezentacje kobiety. Film, reportaż, media” - 17-19 października 2018 roku,

- VI Seminario - styczeń 2019 roku - była to głównie prezentacja książki Ramona Lobo pt. El día que murió Kapuściński („Dzień, w którym umarł Kapuściński”),

- VII Seminario we współpracy z Casa Mediterráneo odbywało się online od września 2020 do stycznia 2021 roku i ze względu na pandemię miało formę wirtualnych spotkań z dziennikarzami (Rosa María Calaf, Guillermo Altares, Clara Jiménez, Mónica García Prieto, Javier Fernández Arribas, Jordi Marí etc.).

Edycje szósta, siódma, a także ósma koncentrują się na tematach związanych z dziennikarstwem, prawami człowieka, migracją, granicami itd. - to kontynuacja cyklu rozpoczętego czwartym seminarium. Organizator dąży również do tego, aby powiązać spotkania z aktualnymi wydarzeniami politycznymi i konfliktami zbrojnymi, żeby przyjrzeć się temu, w jaki sposób pracują korespondenci.

VIII Seminario jest obecnie planowane; organizatorzy pragną powrócić do spotkań na żywo, począwszy od października 2021. 
Tematy pierwszych seminariów zogniskowane były wokół książek polskiego reportażysty, takich jak Imperium, Cesarz, Chrystus z karabinem na ramieniu. Ze strony polskiej w hiszpańskich konferencjach uczestniczyli między innymi: tłumaczka Agata Orzeszek, współautorka biografii Ryszarda Kapuścińskiego - Beata Nowacka ${ }^{4}$, sekretarka autora Hebanu - Agnieszka Flisek, badaczka jego twórczości - Amelia Serraller, a także reporterzy, na przykład Jędrzej Morawiecki oraz Arkadiusz Lewicki i pisząca te słowa. Hiszpańskie środowisko dziennikarskie jest reprezentowane przez wielu reporterów i dziennikarzy, którzy w mniejszym lub większym stopniu identyfikowali się z myślą Ryszarda Kapuścińskiego albo ich sposób pracy przypomina w jakimś stopniu pracę autora Cesarza. W polskich konferencjach uczestniczyli między innymi: José Luis González Esteban, José Alberto García Avilés, Fátima Navarro Maillo, Alicia de Lara, Fernando Olabe, Miguel Carvajal (zespół z UMH), Carlos Elías (UCIII), João Canavilhas (UBI). W organizowanych w IDIKS spotkaniach brali również udział polscy reporterzy i reportażyści, między innymi: Wojciech Cegielski, Jerzy Haszczyński, Lidia Ostałowska, Justyna Kopińska, Angelika Kuźniak, Maciej Skawiński (fotoreporter). Warto nadmienić, że część referatów wygłoszonych w czasie spotkań zostata opublikowana - w zbiorach Cuadernos Ryszard Kapuściński (dwa wydania), w czasopiśmie „Dziennikarstwo i Media”, a owocem czwartej edycji była monografia Periodismo, derechos humanos, migración y fronteras. Vigencia y legado de Ryszard Kapuścinski.

\section{Kapuściński jako mistrz dziennikarstwa}

Celem niniejszego eseju jest zatem próba prześledzenia, w jaki sposób myśl Ryszarda Kapuścińskiego wpływała na środowisko akademickie i dziennikarskie, zwłaszcza w ostatnich dwóch dekadach. Amelia Seraller Calvo ${ }^{5}$ wyróżniła kilka etapów w recepcji polskiego autora w Hiszpanii. Pierwszą książką, która ukazała się w języku hiszpańskim, w tłumaczeniu Agaty Orzeszek i Roberta Mansbergera, był Szachinszach w 1987 roku. Kolejnymi reportażami były Cesarz (1989) i Wojna futbolowa (1992), które jednak trafily do wąskiego grona odbiorców. Jak podaje Serraller Calvo za Jorge Herraldem, „sytuacja zaczęła się poprawiać” w momencie opublikowania Imperium (1994), które spotkało się z większym zainteresowaniem ze strony odbiorców i recenzentów. Od 1995 roku Kapuściński był też korespondentem „El País”. Hiszpańska badaczka zwraca uwagę na fakt, że wydany w 2000 roku Heban spotkał się z bardzo dobrym przyjęciem, ponieważ zbiegł się w czasie z boomem imigracyjnym i potrzebą poszerzenia wiedzy na temat Afryki. Lata, które nastąpiły po przyznaniu Nagrody Księcia Asturii,

\footnotetext{
${ }^{4}$ B. Nowacka, Z. Ziątek, Ryszard Kapuściński. Biografia pisarza, Kraków 2008.

${ }^{5}$ A. Serraller Calvo, La memoria viva de Ryszard Kapuściński en España e Hispanoamérica, „Roczniki Humanistyczne” 2014, nr 5, s. 165-175.
} 
są - zdaniem Serraller Calvo - okresem, kiedy Kapuściński jest uznawany za „mistrza dziennikarstwa"6. Po 2003 roku ukazują się kolejne reportaże: Jeszcze dzień życia, Lapidarium IV, Dzisiejszy świat, Podróże z Herodotem, Ten Inny, Pięć zmystów dziennikarza. Badaczka twórczości polskiego reportera podkreśla, że dowodem uznania w świecie akademickim było nadanie tytułu honoris causa Universitat Ramon Llull (2005). Okres po śmierci Kapu Serraller Calvo określa jako „żywą pamięć o Kapuścińskim”.

Skupiając się na słowach Gonzáleza Estebana, zastanawiałam się, które teksty Kapuścińskiego stanowiły dla Hiszpanów istotny punkt odniesienia i doprowadziły do uznania go za mistrza. Jeżeli chodzi o książki, które można by określić jako „podręczniki dziennikarstwa”, należałoby wymienić co najmniej cztery pozycje, w których pojawia się Kapuściński: Los cinicos no siven para este oficio. Sobre el buen periodismo („To nie jest zawód dla cyników. O dobrym dziennikarstwie") ${ }^{8}$, El mundo de (y a través de) los mass media ${ }^{9}$ („Świat mediów i świat widziany oczami mediów”), Los cinco sentidos del periodista ${ }^{10}$ („Pięć zmysłów dziennikarza”), El Mundo de hoy. Autorretrato de un reportero („Dzisiejszy świat. Autoportret reportera”) ${ }^{11}$. Pierwsza z nich, opatrzona wstępem Marii Nadotti, zawiera trzy rozmowy, które w różnych odstępach czasu przeprowadzili z Kapuścińskim Nadotti i Andrea Semplici, oraz zapis ze spotkania Nadotii, Kapuścińskiego i Johna Bergera. To praca, której główna myśl, w dużym uproszczeniu, opiera się na stwierdzeniu, że dziennikarz musi być przede wszystkim dobrym człowiekiem i kierować się w życiu empatią. Druga publikacja, w zasadzie książeczka, to zapis wykładu, który Ryszard Kapuściński wygłosił na Uniwersytecie w Oviedo 21 października 2003 roku, kiedy otrzymał niezwykle prestiżową nagrodę - Nagrodę Księcia Asturii w zakresie Komunikacji i Działania na rzecz Ludzkości. Chociaż wygłoszony niemalże dwadzieścia lat temu pozostaje niezwykle aktualny. Kapuściński zwrócił w nim uwagę na problem nadmiaru informacji, na to, co dziś określamy mianem szumu medialnego. Reporter podkreślał, że nadmiar prowadzi do utraty umiejętności rozumienia. W rezultacie odbiorca mediów przyjmuje komunikaty, lecz nie przetwarza ich, ponieważ brakuje mu kontekstu kulturowego. Autor Hebanu mówił również o rozróżnieniu journalist i media worker ${ }^{12}$. Kolejna pozycja - Los cinco sentidos... - stała się pozycją kultową nie tylko w Hiszpanii, ale przede wszystkim w Ameryce Łacińskiej, bo to

${ }^{6}$ Tamże, s. 169.

${ }^{7}$ Tamże, s. 170.

${ }^{8}$ R. Kapuściński, Los cínicos no sirven para este oficio. Sobre el buen periodismo, red. M. Nadotti, tłum. X. González Rovira, Barcelona 2009 (wyd. 1, 2002).

${ }^{9}$ Tenże, El mundo de (y através de) los mass media, tłum. A. Orzeszek, Oviedo 2004.

${ }^{10}$ Tenże, Los cinco sentidos del periodista, México, D.F. 2003 (wyd. 2, 2005).

${ }^{11}$ Tenże, El mundo de hoy. Autorretrato de un reportero, red., wstęp i tłum A. Orzeszek, Barcelona 2009 (wyd. 1, 2004).

${ }^{12}$ Tenże, El mundo de (y através de) los mass media, dz. cyt., s. 20. 
właśnie tam, w trakcie warsztatów w Fundación Nuevo Periodismo Iberoamericano (Meksyk 2001, Buenos Aires 2002), Kapuściński przedstawił swoje refleksje, które złożyły się na zawartość książki. Ta lektura stała się obowiązkowa dla wielu dziennikarzy, zwraca bowiem uwagę na kształtowanie się wrażliwości dziennikarskiej opartej na wyostrzeniu zmysłów: bycia, patrzenia, słuchania, dzielenia się i myślenia. Znakomitym dopełnieniem teorii Ryszarda Kapuścińskiego jest ostatnia książka, opracowana i zredagowana przez jego niezłomną tłumaczkę - Agatę Orzeszek. To jej upór i samozaparcie przyczyniły się do rozpowszechnienia myśli Kapuścińskiego w Mundo Hispano. Pierwotny pomysł, aby wydać kompilację wywiadów z Kapuścińskim, należał do, wspomnianej już, Nadotti, następnie w Polsce wydano Autoportret reportera, który ukazuje dwoistą naturę pisarza i reportera. Trzecią książką była antologia tekstów wydana w Niemczech przez Piper Verlag. Orzeszek, podążając za ideą wydawnictwa, dokonała innego wyboru, stworzyła kompilację „,w połowie drogi między polską i niemiecką wersją" ${ }^{3}$, będącą - jak powiada - „naszym portretem" autora Hebanu.

Przywołane teksty, oprócz samych reportaży, zwracają uwagę na istotę zawodu dziennikarza, stają się swoistym dekalogiem i uzupełnieniem idei prezentowanych w reportażach. Do wyżej wspomnianej listy należałoby dorzucić jeszcze bardzo ważną pozycję, która poświęcona jest pracy korespondenta wojennego. Mam tu na myśli Los ojos de la guerra („Oczy wojny”) ${ }^{14}$, która była niejako hołdem dla hiszpańskiego operatora kamery Miguela Gila (1967-2000), który zginął w Sierra Leone 24 maja 2000 roku w wyniku zasadzki. Drugą ofiarą ataku był jego przyjaciel, również korespondent, Kurt Schork. W zbiorze w rozdziale „Refleksje o wojnie i dziennikarstwie” pojawiły się również dwa teksty Ryszarda Kapuścińskiego: Świat ukazany w mediach ${ }^{15}$ oraz Jak postrzegam świat ${ }^{16}$. Wspominam o tym tutaj, ponieważ książka ta stała się cennym źródłem informacji na temat pracy dziennikarza na wojnie oraz zbiorem refleksji o jej etyczno-ludzkim wymiarze. Właśnie na ten aspekt zwraca uwagę Kapuściński, podkreślając, że:

Dzisiaj jest wiele osób, które zajmują się dziennikarstwem, ale robią to nie dlatego, że utożsamiają się z zawodem i podporządkowały mu swoje życie i ambicje. Traktują go jako dodatkowe zajęcie, które w każdej chwili mogą porzucić, aby zająć się czymś innym. Dzisiejszy dziennikarz może rano pracować w agencji reklamowej, a pojutrze rano jako makler giełdowy ${ }^{17}$.

\footnotetext{
${ }^{13}$ A. Orzeszek, Introducción [w:] R. Kapuściński, El mundo de hoy..., dz. cyt., s. 11.

${ }^{14}$ Los ojos de la guerra, red. M. Leguineche, G. Sánchez, Barcelona 2001.

15 Tamże, s. 391-403.

${ }^{16}$ Tamże, s. 404-417.

${ }^{17}$ Tamże, s. 393-394.
} 
Sądzę, że właśnie refleksje Kapuścińskiego na temat etosu zawodu dziennikarskiego przyczyniły się do jego popularności wśród hiszpańskich dziennikarzy i akademików.

Wspomniane seminaria stały się pretekstem do poszukiwań śladów obecności Ryszarda Kapuścińskiego we współczesnym dziennikarstwie w Hiszpanii i w Polsce. I o ile polski kontekst wydaje się dość naturalny, o tyle hiszpańskie konotacje są już mniej oczywiste dla polskiego odbiorcy. W tej kwestii organizatorzy seminariów poszli niejako podwójnym tropem - z jednej strony, poszukując dosłownych nawiązań do Kapuścińskiego, a z drugiej (zwłaszcza w kolejnych edycjach), przyglądając się postawom i zainteresowaniom dziennikarzy. Biorąc pod uwagę ten drugi trop, należałoby skupić się przede wszystkim na stosunku do źródeł/bohaterów reportaży, jak również na sposobie opowiadania/narracji.

Postaram się przybliżyć kilka postaci, które są wskazywane przez badaczy w obu wyżej wspomnianych kontekstach. Są to zarazem autorzy, którzy pojawiają się jako wzorce godne naśladowania dla współczesnych dziennikarzy.

\section{Kapuściński jako wzorzec profesjologiczny i tematologiczny - nawiązania implicytne}

José Alberto García Avilés ${ }^{18}$, profesor z Uniwersytetu Miguela Hernandeza, wskazał czworo reporterów, byłych korespondentów wojennych, których, jego zdaniem, łączy z Kapuścińskim przede wszystkim sposób wykonywania pracy, gotowość do poświęceń, wrażliwość na drugiego człowieka i potrzeba dokumentowania, niezależnie od okoliczności, zagrożenia życia, stanu wojny etc. Badacz twierdzi, że autor Hebanu stworzył nową formułę reportażu, który wykorzystuje narzędzia antropologiczne, historyczne, socjologiczne oraz refleksję antropologiczną w kontekście postrzegania inności. Takie podejście do reportażu charakteryzuje wyróżnionych przez Garcíę Avilésa reporterów, chociaż posługują się oni różnymi środkami wyrazu (słowo, obraz, dźwięk). Kolejnym elementem wspólnym dla polskiego reportera i hiszpańskich dziennikarzy jest skupienie uwagi na tematyce, która wymyka się agencyjnym ramom, na oddaniu głosu tym, którzy go nie mają, bądź tym, którym ten głos odebrano. Wartości bliskie Kapuścińskiemu wspomniany badacz odnajduje u Miguela Gila (1967-2000), Vicente Romero (1947), Rosy Marii Calaf (1945) i Gervasia Sáncheza (1959). Wspomniany już wcześniej Gil był z wykształcenia adwokatem, ale porzucił tę

${ }_{18}$ J.A. García Avilés, „Odkrywanie Innego” - echa twórczości Ryszarda Kapuścińskiego u czterech hiszpańskich reporterów, tłum. M. Kolankowska [w:] Dziennikarstwo i Media 2. Ksztattowanie wizerunku jako narzędzie public relations, red. I. Borkowski, K. Stasiuk-Krajewska, Wrocław 2011, s. 171-183. 
pracę, aby spełnić swoje marzenia i pracować jako korespondent wojenny. Jak pisze García Avilés:

Miguel Gil chciał zdobyć świat poprzez dziennikarstwo. Drogę otworzyła mu w pewnym sensie praca kierowcy wozu opancerzonego, którym przewoził dziennikarzy i pracowników organizacji pozarządowych. Dzięki temu przekraczał linię frontu i nauczył się obsługiwać kamerę. Zdaniem jednej z jego koleżanek, Aidy Cherkez-Robinson z Associated Press, nigdy nie przestał być adwokatem, jednak w pewnym momencie zaczął występować w imieniu pokrzywdzonych, stając twarzą w twarz z publicznością, i przemawiał w ich imieniu ${ }^{19}$.

Ta potrzeba oddania głosu innym, wbrew powszechnej bierności czy wręcz wrogości, prowadziła go z Bośni przez Czeczenię, Kongo, Zair, Sudan, Kosowo do Sierra Leone. Przeciwstawiał się kłamstwu i manipulacjom medialnym, miał też świadomość, że ukazując okrucieństwa wojny, w pewnym sensie uczestniczy w procesie komercjalizacji informacji, ponieważ publika potrzebuje takich „wojennych paparazzich”, a istota dziennikarstwa, zdaniem Gila, polegała na tym, by uświadomić sobie i odbiorcom, że człowiek doświadczający cierpienia „mógłby być twoim synem lub bratem" ${ }^{20}$. Hiszpański medioznawca podkreślał:

Miguel twierdził, że w pewnych historiach „najniebezpieczniejsze jest niepodjęcie ryzyka, aby o nich opowiedzieć, i zaprzestanie filmowania”. I właśnie dlatego on nie wahał się relacjonować konfliktów z pierwszej linii ognia, gotów zostać w Groznym czy w Prisztinie, kiedy inni już sobie pojechali, aby dać świadectwo o niesprawiedliwościach, nadużyciach i zbrodniach oraz łamaniu praw człowieka ${ }^{21}$.

Wrażliwość na krzywdę i cierpienie drugiego człowieka to również cechy, wskazanego przez Garcíę Avilésa, Vicente Romero, który jako korespondent współpracował z wieloma mediami i relacjonował konflikty w Azji, Afryce i Ameryce Łacińskiej. Z Kapuścińskim łączyła go potrzeba bycia z drugim człowiekiem, utożsamienia się z rozmówcą, współodczuwania, wyzbycia się poczucia wyższości, sztuczności, jak również potrzeba zaangażowania się w sprawy innych:

Nie potrafię zrozumieć, jak można jechać w miejsca nieszczęścia i nie wzruszać się. Dzień, w którym przyzwyczaję się do niesprawiedliwości, będzie znakiem, bym przestał jeździć. Dopóki potrafisz wzruszać się i złościć na innych i nie wpadasz w pułapkę obiektywizmu dziennikarskiego, ten zawód [korespondenta] nie tylko ma sens, ale też jest tym, który najbardziej ubogaca i jest najbardziej potrzebny w dziennikarstwie ze względu na to, że charakteryzuje go solidarność z innymi

\footnotetext{
19 Tamże, s. 173.

${ }^{20}$ Tamże, s. 174.

21 Tamże.
} 
i obrona ostatniego bastionu, jakim jest bieda - najbardziej radykalny przykład niesprawiedliwości ${ }^{22}$.

García Avilés podkreślał nie tylko wrażliwość Romero na krzywdę, ale także jego niezłomną walkę ze zmową milczenia, zwłaszcza w odniesieniu do tragedii, o których wszyscy zapomnieli, miejsc wojen i kataklizmów, z których inni reporterzy wyjechali, goniąc za kolejną sensacją. Dla korespondenta równie ważny powinien być ten czas, w którym trzeba zmierzyć się ze skutkami nieszczęść, zacząć nowe życie. Vicente Romero opowiada się zatem za odpowiedzialnością za drugiego człowieka, za dziennikarstwem zaangażowanym, podobnie jak Kapuściński.

Niezwykle ważną w gronie wskazanych przez Garcí Avilésa postaci jest Rosa María Calaf, wieloletnia korespondentka TVE, która była świadkiem kluczowych wydarzeń w Stanach Zjednoczonych, rozpadu Związku Radzieckiego, transformacji ustrojowych w Ameryce Łacińskiej (Chile, Argentyna), jak również wielu innych wydarzeń na całym świecie. Jej oczami Hiszpania poznawała inne kultury, dowiadywała się o nadużyciach władzy, manipulacjach, konfliktach zbrojnych. Zawsze czyniła to z dużą uważnością i szacunkiem do swoich bohaterów i odbiorców. To, co jej zdaniem stało się podstawowym problemem w dziennikarstwie telewizyjnym, to ograniczenia czasowe prowadzące do nadmiernych, a tym samym niebezpiecznych, uproszczeń. Innymi czynnikami są, jak pisze García Avilés, zależność finansowa i ekonomiczna oraz „widowiskowość i banał”. I to właśnie łączy ją z refleksją Kapuścińskiego: konieczność objaśniania skomplikowanej, odmiennej rzeczywistości, którą korespondent niejako filtruje przez pryzmat swojej wiedzy i doświadczeń.

Czwartym reporterem, o którym pisze García Avilés, jest Gervasio Sánchez, wieloletni korespondent wojenny i zagraniczny, który jest znany głównie z niezwykłych zdjęć - fotoreportaży i fotoprojektów, między innymi „Okrucieństwa wojny" (to również tytuł jego bloga, skojarzenie z Goyą jest jak najbardziej celowe), „Życie na minie (Vidas minadas)”, „Zaginieni. Ofiary zapomnienia (Desaparecidos. Víctimas del olvido)". Podobnie jak pozostali był wysłannikiem w wielu miejscach na całym świecie: od Europy po Azję, Afrykę i Amerykę Łacińską. Z Kapuścińskim łączy go dwupoziomowe relacjonowanie poprzez obraz i słowo. Sánchez nie podziela opinii, że dziennikarstwo powinno być zaangażowane, ale wyraźnie staje po stronie ofiar. Jego zdjęcia są przejmujące, pełne empatii, ale nie epatujące okrucieństwem.

Oddaje w nich głos tym, którzy już nie mogą krzyczeć ani płakać z bólu, ale ten ból na fotografiach staje się niejako namacalny. Reporter często wykorzystuje detale, które stają się Punctum obrazu, o którym pisał Roland Barthes ${ }^{23}$ - na przy-

${ }^{22}$ V. Romero, [wywiad], „El Magazine de El Mundo”, 4.06.2000, nr 36 [w:] J.A. García Avilés, dz. cyt., s. 175 .

${ }^{23}$ R. Barthes, Światto obrazu. Uwagi o fotografii, thum. J. Trznadel, Warszawa 2008. 
kład w projekcie „Zaginieni”” ${ }^{4}$, który poświęcony jest wymuszonym zniknięciom ludzi w Ameryce Łacińskiej, Azji, na Bliskim Wschodzie. Uwagę widza przykuwają drobne pamiątki: grzebień, szczotka, maskotka, różaniec itp. W tym skupieniu na szczegółach upodabnia się do Kapuścińskiego, który wielokrotnie właśnie w detalach odkrywał klucze do objaśniania rzeczywistości ${ }^{25}$.

García Avilés, podsumowując swoje refleksje, wskazuje na etyczny wymiar pracy korespondentów:

Wspólnym mianownikiem dla tej czwórki dziennikarzy jest podjęcie zobowiązań etycznych. Ich wrażliwość, ich zdolność do zajmowania się problemami zwykłych ludzi, ich miłość do tych pozostających na marginesie, wykluczonych. Dać głos Innemu, o czym mówił Ryszard Kapuściński. Dzięki jego zdolności do obserwowania rzeczywistości ci reporterzy, tak jak ich znakomity kolega z Polski, zrozumieli, że bycie odpowiedzialnym wykracza poza chłodne relacjonowanie zdarzen ${ }^{26}$.

González Esteban ${ }^{27}$ zauważa, że styl Kapuścińskiego miał wpływ na hiszpańskie dziennikarstwo zarówno przed przyznaniem Nagrody Księcia Asturii, jak i po niej. Drugim momentem, który przyczynił się do wzmocnienia jego pozycji w Hiszpanii, było nadanie tytułu honoris causa Uniwersytetu Ramona Llulla w Barcelonie w 2005 roku. Trzecim zaś było przyznanie kolejnej prestiżowej nagrody - Fundacji Miguela Gila Moreno i wydawnictwa Random House Mondadori w 2006 roku. Odnosząc się do konkretnych przykładów, hiszpański medioznawca podziela opinię Garcíi Avilésa ${ }^{28}$, przy czym czwórkę przywołaną przez kolegę określa mianem weteranów. Wśród nich szczególnie podkreśla znaczenie Gervasia Sáncheza i Rosy Maríi Calaf. Tę drugą wyróżnia jako pierwszy kobiecy głos „reporterki z międzynarodowym powołaniem”29. Do wcześniejszej listy dorzuca także Ramóna Lobo ${ }^{30}$ (1955), o którym jeszcze będzie mowa w dalszej

${ }^{24}$ Zob. M. Kolankowska, Narracja obrazem na przyktadzie projektu Gervasia Sáncheza pt. „Desaparecidos. Victimas del olvido" [w:] "Jestem kulturowym mieszańcem. I to mi siępodoba...". Ksiegga jubileuszowa dedykowana Profesorowi Andrzejowi Zawadzie z okazji 70. rocznicy urodzin, red. I. Borkowski, A. Lewicki, P. Urbaniak, Kraków 2018, s. 263-281.

${ }^{25}$ B. Nowacka, Magiczne dziennikarstwo. Ryszard Kapuściński w oczach krytyków, Katowice 2006 , s. 21.

${ }^{26}$ J.A. García Avilés, dz. cyt., s. 183.

${ }^{27}$ J.L. González Esteban, Redefinición y discusión sobre el reportaje a partir de la obra de Kapuścinski: debate hispano-polaco, „Itinerarios. Revista de estudios lingüísticos, literarios, históricos y antropológicos" 2010, nr 12, s. 281-296.

${ }^{28}$ Tekst Garcíi Avilésa ukazał się najpierw w wersji hiszpańskiej w Cuaderno de Comunicación Ryszard Kapuściński, red. J.L. González Esteban, 2010, a następnie w wersji polskiej, którą cytuję, ale chronologicznie był pierwszy.

${ }^{29}$ J.L. González Esteban, dz. cyt., s. 293.

${ }^{30}$ Ramón Lobo był wieloletnim korespondentem dziennika „El País” (w Ameryce Łacińskiej, Afryce, Azji, na Bliskim Wschodzie), po redukcjach w redakcji musiał rozstać się z gazetą, ale od roku 2018 wrócił do pracy i pisze swoją kolumnę. Współpracował z licznymi mediami. 
części, jak również Artura Péreza-Reverte, pisząc, że jego Terytorium Komanczów to „najbardziej Kapuściński moment” ${ }^{31}$.

\section{Kapuściński jako wzorzec profesjologiczny i tematologiczny - nawiązania eksplicytne}

González Esteban twierdzi, że obok „weteranów” należy też wskazać młodsze pokolenie dziennikarzy, „u którego widoczny jest wpływ Kapuścińskiego” ${ }^{2}$. Zalicza do nich Francisca Peregila (1967), który jest korespondentem zagranicznym dziennika „El País”. Hiszpański medioznawca wyróżnia jego pracę, ponieważ po powrocie z drugiej wojny w Zatoce Perskiej napisał zbiór Reportero en Bagdad: historia de una guerra polémica („Reporter w Bagdadzie - historia polemicznej wojny") ${ }^{33}$, oparty na własnych doświadczeniach. Kolejną osobą, którą wskazał jako przedstawicielkę tego młodego pokolenia, jest Olga Rodríguez (1975), autorka kilku reportażowych publikacji poświęconych głównie Bliskiemu Wschodowi. González Esteban zwrócił uwagę na dwie pozycje: Aqui Bagdad: crónica de una guerra ${ }^{34}$ i El hombre mojado no teme la lluvia: voces de Oriente Medio ${ }^{35}$ oraz książkę, której była współautorką, poświęconą historii tragicznie zmarłego przyjaciela, operatora kamery, José Couso ${ }^{36}$.

W moim przekonaniu do powyższej listy należałoby dodać również innych dziennikarzy, o czym mówiłam w trakcie IV Congreso Internacional Latina de Comunicación Social w grudniu 2012 roku $^{37}$. W mojej analizie skoncentrowałam się zarówno na pracy wyżej wspomnianych - Olgi Rodríguez, Ramóna Lobo,

Był wielokrotnie nagradzany za swoją działalność dziennikarską. Otwarcie mówi o swojej fascynacji Kapuścińskim, czemu daje wyraz w kolejnych publikacjach. Autor kilku książek non-fiction: El héroe inexistente. Los viajes de un corresponsal de guerra al corazón de las tinieblas del fin de siglo, Isla África, Cuadernos de Kabul. Historias de mujeres, hombres y niños atrapados en una guerra, El autoestopista de Grozni y otras historias de fútbol y guerra, Todos náufragos, El día que murió Kapuściński, Las ciudades evanescentes. Miedos, soledades y pandemias en un mundo globalizado.

${ }^{31}$ J.L. González Esteban, dz. cyt., s. 292.

${ }^{32}$ Tamże, s. 293.

${ }^{33}$ F. Peregil, Reportero en Bagdad: historia de una guerra polémica, Barcelona 2003.

${ }^{34}$ O. Rodríguez, Aqui Bagdad: crónica de una guerra, Madrid 2004.

${ }^{35}$ Tenże, El hombre mojado no teme la lluvia: voces de Oriente Medio, Barcelona 2009.

${ }^{36}$ José Couso (1965-2003) - hiszpański operator kamery, zginął pod ostrzałem czołgów armii amerykańskiej, gdy nagrywał film z hotelu Palestina w Bagdadzie. Rodzina i przyjaciele do dziś domagają się wyjaśnienia okoliczności śmierci, ale trwa zmowa milczenia. Przyjaciele, reporterzy, napisali książkę José Couso: La mirada incómoda, (b.m.) 2004.

${ }^{37}$ M. Kolankowska, ¿Sigue vivo Ryszard Kapuśsiński? El encuentro con el Otro durante el conflicto en el reportaje actual español [w:] C.M. Barber, Información y conflicto: los medios ante la violencia, La Laguna 2014. 
Gervasia Sáncheza, jak i na działaniach Davida Beriaina ${ }^{38}$ (1977-2021), Mikela Ayestarána ${ }^{39}$ (1975), Moniki Bernabé (1972) ${ }^{40}$ i Hernána Zina (1971) ${ }^{41}$. U wielu z nich znalazłam bezpośrednie odniesienia do twórczości autora Szachinszacha. Dzisiaj do tej listy dorzuciłabym niewątpliwie Xaviera Aldekoęę2 (1981), który całym sercem związany jest z Afryką - o niej pisze, mówi i ją kocha, jak również grono dziennikarzy współtworzących magazyn „Revista $5 \mathrm{~W}$ ”. To, co ich łączy, to ukierunkowanie na obszary, które nie są ujęte w głównych agendach, zwłaszcza kraje Trzeciego Świata i Bliski Wschód, wrażliwość na drugiego człowieka, empatia, a przede wszystkim wykorzystanie języka literatury - niekiedy w połączeniu z przekazem audiowizualnym. Ten Inny, którego spotykają, ma odmienne spojrzenie na świat, co starają się uchwycić wspomniani korespondenci. Dziennikarze, podobnie jak Kapuściński, wychodzą poza europo- czy etnocentryczną perspektywę, aby przełamać obowiązujące w społeczeństwie stereotypy. $\mathrm{Z}$ empatii, współodczuwania rodzi się zrozumienie i konieczność przetransponowania doświadczenia na odbiorcę. Takie postrzeganie zawodu wiąże się z zaangażowaniem, o którym niejednokrotnie mówił Kapuściński, stając w opozycji do, postulowanego w dziennikarstwie agencyjnym, obiektywizmu. Charakterystyczne dla tych autorów jest również skupienie się na detalach, które urastają do rangi symboli, Beriain mówił wręcz o pokazywaniu wojny „z perspektywy

${ }^{38}$ David Beriain zginął 26 kwietnia 2021 roku, wraz z Robertem Frailem oraz Rorym Railem, w Burkina Faso. Został zamordowany przez Nusrat al-Islam w czasie kręcenia filmu dokumentalnego. Jego śmierć wstrząsnęła światem dziennikarskim. To kolejny hiszpański reporter, który ginie w wyniku ataku, pełniąc swoją służbę. Beriain współpracował z wieloma redakcjami, współtworzył grupę REC, prowadził blog „En pie de guerra” (http://www.enpiedeguerra.tv/www.enpiedeguerra.tv/Reportajes.html, dostęp: 5.06.2021). Był wielokrotnie nagradzany za swoją pracę.

${ }^{39}$ Mikel Ayestarán jest freelancerem, stale współpracuje z grupami EiTB y Vocento. Jest autorem filmów dokumentalnych oraz książek Jerusalén, santa y cautiva, Las cenizas del califato, Ekialde Hurbila, muinak eta ertzak, Oriente Medio, Oriente roto, Gaza, cuna de mártires, Guerra de ayer y boy (z Ramónem Lobo). Strona oficjalna: https://www.mikelayestaran.com/libros/, dostęp: 5.06.2021.

${ }_{40}^{40}$ Mónica Bernabé - hiszpańska dziennikarka, zasłynęła jako korespondentka w Afganistanie, gdzie spędziła osiem lat. Autorka książek: Afganistán, crónica de una ficción oraz Mujeres. Afganistán (wybór zdjęć, we współpracy z G. Sanchezem). Lauretka kilku prestiżowych nagród.

${ }^{41}$ Hernán Zin jest dziennikarzem pochodzenia argentyńsko-włoskiego, ale od ponad dwudziestu lat mieszka w Hiszpanii. Jest reporterem, dokumentalistą, producentem, autorem kilku książek reportażowych: Querida guerra mía, Llueve sobre Gaza, La libertad del compromiso, Helado y patatas fritas, Un voluntario en Calcuta. Był wielokrotnie wyróżniany za swoją pracę.

${ }^{42}$ Xavier Aldekoa jest freelancerem, związany z „Revista 5W”, autor licznych reportaży oraz książek: Hijos del Nilo, Oceano África. Strona oficjalna: http://www.xavieraldekoa.net/reportajes/, dostęp: 5.06.2021.

${ }^{43}$ Zob. M. Kolankowska, Slow journalism w środowisku cyfrowym na przyktadzie „Revista 5W". Crónicas de larga distancia [w:] Studia i perspektywy medioznawcze 2, red. K. Konarska, P. Urbaniak, Wrocław 2020. 
różnych mikrokosmosów" "44 akcentował też konieczność nawiązywania bliskich relacji z bohaterami tekstów:

Jak mawiał Kapuściński: „Zadaniem dziennikarza jest współodczuwanie z ludźmi tego, co przeżywają; jest to jedyny sposób uzyskania prawa do pisania o ich życiu”. Bycie tam jest być może jedyną formą wyeliminowania tego dystansu istniejącego pomiędzy nami a wojną, którą chcemy relacjonowaćc ${ }^{45}$.

Ta refleksja stała się niezwykle prawdziwa w kontekście śmierci Beriaina. Był tak blisko wojny, że stał się jej ofiarą. W swojej pracy podkreślał wagę spotkania, czuł się odpowiedzialny za drugiego człowieka, nawet u największych zbrodniarzy potrafił znaleźć głębię człowieczeństwa - co ujawniło się w rozmowie z przywódcą FARC. Jego rozmowy były trochę jako otwieranie matrioszki - każda kolejna lalka kryła w sobie następną, aż do tej najmniejszej, która stanowiła sedno. To również wspólna cecha wymienionych tu dziennikarzy - w swoich relacjach i książkach pragną ukazać istotę rzeczy - raz dobra, raz zła. Bardzo silne jest to poczucie odpowiedzialności za słowo i zaangażowanie. To dziennikarstwo, które ma objaśniać i zmieniać świat, rozszerzać perspektywy - jak pisze Olga Rodríguez w prologu do El hombre mojado no teme la lluvia:

Nadrzędnym celem tej książki jest opowiedzieć bez oceniania, przypisać imiona, głosy i twarze ludziom, którzy zwykle są przedstawiani wyłącznie jako element wielkiej masy, którą nazywamy Arabami, muzułmanami czy Żydami. Bohaterami tej książki są mężczýnini i kobiety, których stopniowo poznawałam w trakcie moich pobytów w Iraku, Izraelu, na okupowanych terytoriach palestyńskich, w Libanie, Syrii, Egipcie i Afganistanie. Ich historie zwykle nie pojawiają się w głównych tytułach gazet, ale stanowią klucze i detale niezbędne do zrozumienia, jaki jest Bliski Wschód i co się tam dzieje ${ }^{46}$.

Reporterka tłumaczy tę postawę w jednym z wywiadów, podkreślając swój związek z autorem Lapidariów:

Uważam, że żyjemy w czasach, kiedy mamy nadmiar informacji, ale to nie oznacza, że jesteśmy dobrze poinformowani. Myślę, że ważne są kontekstualizacja, pogłębienie, wyjaśnienie, włączenie Historii do historii. Jak mawiał mistrz Kapuściński, to właśnie poprzez małe historie rozumie się Historię. Niekiedy my dziennikarze

${ }^{44}$ I. González Mesa, J.L. González Esteban, M. Carvajal, Reinventar los medios locales, Murcja 2009 , s. 35 .

${ }^{45}$ Tamże, s. 38.

${ }^{46}$ O. Rodríguez, El hombre mojado no teme la lluvia..., dz. cyt., s. 15-16. 
mamy do dyspozycji tylko mikroprzestrzeń, aby opowiedzieć to, co widzimy, i pozostawiamy znaczną część informacji ${ }^{47}$.

Ta potrzeba znalezienia kluczy do zrozumienia towarzyszy każdemu z nich. Zin podobnie jak Kapuściński - niejednokrotnie wykorzystuje jako znaczący detal buty, bo stają się one oznaką prestiżu wśród biednych dzieci biegających po argentyńskich ulicach. Możesz nie mieć nic, ale jeśli masz buty, jesteś kimś - zdaje się mówić hiszpański reporter. W innym materiale, już niedostępnym w internecie, pokazuje urywki z pracy przy filmie - w afrykańskiej wiosce spotyka dzieci, które bawią się owadami - z naszej, europocentrycznej perspektywy, może się to wydawać barbarzyństwem, ale dla nich złapany owad, przytwierdzony do patyczka, jest przednią zabawą, podobnie jak znalezione butelki, blachy i inne przedmioty. Zin śmieje się, bawi się z nimi, dzieli się z odbiorcami doświadczeniem beztroski, czymś, czego niezwykle brakuje współczesnym. To chwila, to rzeczywistość równoległa - świat widziany oczami najmłodszych. Właśnie ta uważność łączy i jego z Kapuścińskim.

Najbardziej oddanym uczniem Kapu jest, wspomniany już kilkakrotnie, Ramón Lobo, który czuje wyjątkową więź z polskim reporterem, czemu niejednokrotnie dał wyraz. Lobo przeprowadził wywiad z Ryszardem Kapuścińskim w 2006 roku $^{48}$ i powstała $z$ tego bardzo intymna sylwetka pisarza. Widać w tym opisie duże zaangażowanie Lobo, wzruszenie, ale też i fascynację człowiekiem. Sam tytuł rozmowy zdaje się charakteryzować obu rozmówców: „Sensem życia jest przekraczanie granic". Lobo wyłuskuje z tego spotkania myśli na kształt aforyzmów. Te odniesienia znajdą się później w jego książce Cuadernos de Kabul ${ }^{49}$ nawet przywołuje Kapuścińskiego w tytule jednego z rozdziałów: Hotele, Kapuściński i kompetencja. W tym reportażu z Afganistanu odnosi się wrażenie, jak gdyby podróżowali wspólnie, zwłaszcza w momentach samotności, w pustym pokoju hotelowym Lobo zdaje się prowadzić wewnętrzną rozmowę z mistrzem, odtwarza jego zachowania, „liturgie podróży”, na przykład, rozkładając przedmioty, które mają mu pomóc oswoić przestrzeń. Wyznaje przy tym: „Zawsze naśladowałem w tym Kapuścińskiego, nie wiedząc tak naprawdę, w czym go naśladowałem ani też po co to robiłem. To właśnie różnica pomiędzy geniuszem i reporterem" ${ }^{\text {"50 }}$.

Lobo stroni od luksusowych miejsc, krąży po zakamarkach Kabulu i towarzyszy mu przekonanie, że Kapuściński zrobiłby to samo. Przygląda się ludziom, miejscom, snuje refleksje, szuka metafor, które pozwoliłyby mu nakreślić realia, oddając przy tym atmosferę zagrożenia.

${ }^{47}$ Entrevista con Olga Rodríguez, „El País”, https://elpais.com/internacional/2009/06/15/actualidad/1245056400_1245061793.html, dostęp: 15.06.2021.

${ }^{48}$ R. Lobo, [wywiad z Ryszardem Kapuścińskim] El sentido de la vida es cruzar fronteras, „El País", 23.04.2006, https://elpais.com/diario/2006/04/23/domingo/1145764354_850215.html, dostęp: 15.06.2021.

${ }^{49}$ Tenże, Cuadernos de Kabul, Barcelona 2010.

${ }^{50}$ Tamże, s. 32. 
Autor Cuadernos de Kabul uczestniczył również w seminariach organizowanych w Elche, gdzie niejednokrotnie odwoływał się do swojej fascynacji Ryszardem Kapuścińskim, ale chyba najbardziej wymownym jej dowodem jest jego ostatnia książka El día que murió Kapuściński - powieść non-fiction, oparta na doświadczeniach korespondenta wojennego. Książka ${ }^{51}$ miała być formą uczczenia pamięci hiszpańskiego dziennikarza „El País”, Juana Carlosa Gumucio, który zginął w 2002 roku. Dzień śmierci Kapuścińskiego staje się punktem wyjścia tej opowieści, wyznacza koniec pewnej epoki, powolnego dziennikarstwa (slow journalism, periodismo lento), które, zdaniem Lobo, zanikło:

Chcę powiedzieć, że powolne dziennikarstwo, wyjazdy w odległe miejsca, dysponowanie czasem i cierpliwością, aby dowiedzieć się dobrze, co się dzieje, zanikło. To zbiegło się ze śmiercią Kapuścińskiego. (...) Kapuściński jest przedstawicielem powolnego dziennikarstwa, bycia na miejscu, a następnie pisania.

Oskarżono go o wymyślanie historii, ale cóż, w przypadku polskiego dziennikarza, który z perspektywy czasu pisał dla polskiej agencji o Etiopii, mogło dojść do pewnych uproszczeń i nadinterpretacji. Natomiast w dziennikarstwie agencyjnym i w gazecie nie może być o tym mowy. Ja nie mam w tej kwestii żadnego problemu z Kapuścińskim, jeżeli trzeba będzie zmienić jego książki z literatury faktu na fikcję, trzeba będzie to zrobić, ale to nie zmienia faktu, że są nadzwyczajne. Dla mnie jest to typ dziennikarza, który reprezentuje symboliczny koniec pewnej epoki ${ }^{52}$.

\section{Podsumowanie}

Ryszard Kapuściński stał się dla hiszpańskich medioznawców przede wszystkim mistrzem dziennikarstwa. W działalności akademickiej zwracają oni uwagę na wskazówki dotyczące dobrych praktyk, traktowanie Innego, oddanie głosu tym, którym ów głos odebrano. W trakcie polsko-hiszpańskich seminariów rozmawiano o etycznym wymiarze dziennikarstwa, zwłaszcza w kontekście łamania praw człowieka w różnych rejonach świata. Organizowane konferencje dowodzą, że myśl Ryszarda Kapuścińskiego jest wciąż żywa i aktualna i może stanowić punkt wyjścia do dalszych refleksji na temat zawodu reportera i jego granic. Jednocześnie staje się jasne, że obszary takie jak Afryka czy Bliski

${ }^{51}$ M. López, Kapuściński, la guerra y el periodismo, elperiodico.com, 29.04.2019, https://www. elperiodico.com/es/ocio-y-cultura/20190429/Kapuściński-la-guerra-y-el-periodismo-segun-ramon-lobo-7411758, dostęp: 15.06.2021.

${ }^{52}$ Casa Mediterráneo, Ramón Lobo: „Kapuściński representa esa época del periodismo lento que ha desaparecido", https://www.casa-mediterraneo.es/ramon-lobo-kapuscinski-representa-esa-epoca-del-periodismo-lento-que-ha-desaparecido/, dostęp: 15.06.2021. 
Wschód nadal są wypierane z głównych agend, a ich problemy są marginalizowane. Istnieje potrzeba opisywania i objaśniania złożonej rzeczywistości, którą często stygmatyzujemy lub staramy się uprościć, przykładając zakodowane klisze. Współczesne powolne dziennikarstwo ma bardzo poważne zadanie: tłumaczyć i edukować.

Hiszpańscy dziennikarze, zarówno starszego, jak i młodszego pokolenia, odwołują się do myśli polskiego reportera w sposób pośredni lub bezpośredni. Nawiązania implicytne i eksplicytne skupiają się przede wszystkim na aspektach profesjologicznych i tematologicznych. Dla wielu dziennikarzy i akademików Kapuściński pozostaje mistrzem, wzorem do naśladowania, zwłaszcza jeśli chodzi o traktowanie drugiego człowieka i wyjaśnianie odmiennych realiów. To on uczy ich skupienia na detalu, drobiazgu, potrzeby wsłuchania się w głos bohaterów. Działania podejmowane na Uniwersytecie Miguela Hernandeza dowodzą, że studentom, szczególnie dziś, w czasach zdominowanych przez media workers, w erze nadmiaru informacji, potrzeba rozmowy i refleksji na temat istoty dziennikarstwa. Twórczość Kapuścińskiego staje się punktem wyjścia do dyskusji, otwiera na inność.

\section{Bibliografia}

Barthes R., Światto obrazu. Uwagi o fotografii, thum. J. Trznadel, Warszawa 2008. Blog „En pie de guerra”, http://www.enpiedeguerra.tv/www.enpiedeguerra.tv/Reportajes.html, dostęp: 5.06.2021.

Casa Mediterráneo, Ramón Lobo: „Kapuściński representa esa época del periodismo lento que ha desaparecido", https://www.casa-mediterraneo.es/ramon-lobo-kapuscinski-representa-esa-epoca-del-periodismo-lento-que-ha-desaparecido/, dostęp: 15.06.2021.

Cuaderno de Comunicación Ryszard Kapuścinsski, red. J.L. González Esteban, 2009.

Entrevista con Olga Rodríguez, „El País”, https://elpais.com/internacional/2009/06/15/ actualidad/1245056400_1245061793.html, dostęp: 15.06.2021.

García Avilés J.A., Odkrywanie Innego - echa twórczości Ryszarda Kapuścińskiego u czterech hiszpanskich reporterów, tłum. M. Kolankowska [w:] Dziennikarstwo i Media 2. Ksztaltowanie wizerunku jako narzędzie public relations, red. I. Borkowski, K. Stasiuk-Krajewska, Wrocław 2011.

González Esteban J.L., Redefinición y discusión sobre el reportaje a partir de la obra de Kapuściński: debate hispano-polaco, „Itinerarios. Revista de estudios lingüísticos, literarios, históricos y antropológicos" 2010, nr 12.

González Esteban J.L., López-Rico C.M., Periodismo, derechos humanos, migración y fronteras. Vigencia y legado de Ryszard Kapuściński, Murcja 2017.

González Mesa I., González Esteban J.L., Carvajal M., Reinventar los medios locales, Murcja 2009.

José Couso: La mirada incómoda, Hermanos, Amigos y Compañeros de José Couso, (b.m.) 2004. 
Kapuściński R., El mundo de hoy. Autorretrato de un reportero, red., wstęp i tłum. A. Orzeszek, Barcelona 2009 (wyd. 1, 2004).

Kapuściński R., El mundo de (y através de) los mass media, tłum. A. Orzeszek, Oviedo 2004.

Kapuściński R., Los cinco sentidos del periodista, México, D.F. 2003.

Kapuściński R., Los cinicos no sirven para este oficio. Sobre el buen periodismo, red. M. Nadotti, tłum. X. González Rovira, Barcelona 2009 (wyd. 1, 2002).

Kolankowska M., Narracja obrazem na przyktadzie projektu Gervasia Sáncheza pt. „Desaparecidos. Victimas del olvido" [w:] "Jestem kulturowym mieszańcem. I to mi siępodoba.... Ksiega jubileuszowa dedykowana Profesorowi Andrzejowi Zawadzie z okazji 70. rocznicy urodzin, red. I. Borkowski, A. Lewicki, P. Urbaniak, Kraków 2018.

Kolankowska M., ¿Sigue vivo Ryszard Kapuścinski? El encuentro con el Otro durante el conflicto en el reportaje actual español [w:] C.M. Barber, Información y conflicto: los medios ante la violencia, La Laguna 2014.

Kolankowska M., Slow journalism wśrodowisku cyfrowym na przyktadzie Revista 5 W. Crónicas de larga distancia [w:] Studia i perspektywy medioznawcze 2, red. K. Konarska, P. Urbaniak, Wrocław 2020.

Lobo R., Cuadernos de Kabul, Barcelona 2010.Lobo R., [wywiad z Ryszardem Kapuścińskim] El sentido de la vida es cruzar fronteras, „El País”, 23.04.2006, https:/ / elpais.com/diario/2006/04/23/domingo/1145764354_850215.html, dostęp: 15.06.2021.

López M., Kapuściński, la guerra y el periodismo, elperiodico.com, 29.04.2019, https:// www.elperiodico.com/es/ocio-y-cultura/20190429/Kapuściński-la-guerra-y-el-periodismo-segun-ramon-lobo-7411758, dostęp: 15.06.2021.

Los ojos de la guerra, red. M. Leguineche, M. Sánchez, Barcelona 2001.

Nowacka B., Magiczne dziennikarstwo. Ryszard Kapuścinski w oczach krytyków, Katowice 2006.

Nowacka B., Ziątek Z., Ryszard Kapuściński. Biografia pisarza, Kraków 2008

Peregil F., Reportero en Bagdad: historia de una guerra polémica, Barcelona 2003.

Rodríguez O., Aqui Bagdad: crónica de una guerra, Madrid 2004.

Rodríguez O., El hombre mojado no teme la lluvia: voce de Oriente Medio, Barcelona 2009.

Serraller Calvo A., La memoria viva de Ryszard Kapuściński en España e Hispanoamérica, „Roczniki Humanistyczne” 2014, nr 4.

Strona oficjalna: http://www.xavieraldekoa.net/reportajes/, dostęp: 5.06.2021.

Strona oficjalna: https://www.mikelayestaran.com/libros/, dostęp: 5.06.2021. 